УдК: 004.94.355

Олександр Валерійович Крайнов (кандидат технічних наук, доцент) ${ }^{1}$

Роман Іванович Грозовський

Анатолій Анатолійович Кравчук ${ }^{2}$

${ }^{1}$ Національний університет оборони Украӥни імені Івана Черняховського, Київ, Украӥна

${ }^{2}$ Військовий інститут Киӥвського національного університету ім. Т. Шевченка, Кийв, Украйна

\title{
МЕТОДИКА ОЦІНКИ ЯКОСТІ ІНФОРМАЦІЙНО-АНАЛІТИЧНОГО ЗАБЕЗПЕЧЕННЯ РОБОТИ АВТОМАТИЗОВАНИХ ІНФОРМАЦІЙНИХ СИСТЕМ ОРГАНІВ УПРАВЛІННЯ ВІЙСЬКОВОГО ПРИЗНАЧЕННЯ
}

Одним із пріоритетних завдань оборонної реформи є створення ефективної системи управління військового призначення. Важливу роль у реалізації цъього завдання відіграватимуть впровадження в діяльність органів управління та військ (сил) сучасних інформаційних технологій, адаптація найкращих практик та стандартів провідних краӥн-членів НАТО, комплексна автоматизація процесів оперативного (бойового) управління, зв'язку, розвідки та спостереження (C4ISR), обліку та управління оборонними ресурсами (DRMIS). Проблемним питанням залишається здійснення та виконання замовлень щуодо створення автоматизованих інформаційних систем органів управління військового призначення, інформачійно-аналітичного забезпечення їх роботи та інформачійної інфраструктури, оскільки в Украӥні на цей час відсутні державні організації та приватні підприємства, які здатні самостійно виконувати увесь комплекс робіт і послуг із створення автоматизованих інформаційних систем та розгортання інформачійної інфраструктури.

Ключові слова: автоматизована інформачійна система; інформачійно-аналітичне забезпечення; орган військового управління; якість.

\section{Вступ}

Постановка проблеми. Основна проблема організації інформаційно-аналітичного забезпечення сучасних інформаційних систем органів управління військового призначення рішення протиріччя між збільшенням обсягу необхідної інформації і постійною вимогою до скорочення часу на її обробку. Причому саме вона визначає тенденції в розвитку цих систем, у тому числі, й підвищенні якості інформаційноаналітичного забезпечення роботи автоматизованих інформаційних систем (AIC) органів управління військового призначення.

Розв'язання зазначеної проблеми потребує здійснення невідкладних, цілеспрямованих, скоординованих за термінами, обсягами ресурсного забезпечення заходів щодо створення AIC органів управління військового призначення, інформаційно-аналітичного забезпечення систем управління, інформаційної інфраструктури у рамках окремих відомчих програм, які мають стати основоположними документами для бюджетного планування на короткострокову та середньострокову перспективу. Інформаційноаналітичне забезпечення роботи AIC органів управління військового призначення містить у собі комплекс заходів (сукупність усіх видів діяльності), спрямованих на збір, передачу, збереження, захист, обробку, видачу i надання даних споживачам інформації для виконання ними своїх функціональних обов'язків. У його здійсненні беруть участь різнорідні по своєму складу і призначенню сили і засоби.
Важливою особливістю роботи органів управління 3 використанням автоматизованих систем управління військами (АСУВ) та АIC є те, що весь процес управління представляє собою інформаційно-аналітичний процес в єдиному інформаційному просторі системи управління, i який направлений на вирішення завдань інформаційно-аналітичного забезпечення органів управління військового призначення.

Інформаційно-аналітичне забезпечення органів управління військового призначення - це сукупність інформаційних продуктів, ресурсів і послуг, які надаються для забезпечення інформаційних потреб посадових осіб органів управління, і система підтримки ухвалення рішень їх управлінської діяльності.

Аналіз остатніх досліджень і публікацій.

На даний час відомо три методи інформаційноаналітичної підтримки роботи органів управління [1,3]: аналогія, метод статистичного аналізу i метод вивчення окремих випадків (рис. 1.).

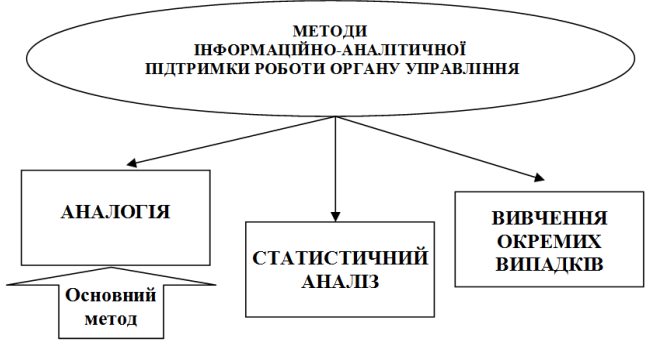

Рис. 1. Методи інформаційно-аналітичної підтримки роботи органів управління. 
Основним методом інформаційно-аналітичної підтримки роботи органів управління військового призначення доцільно вважати аналогію, так як даний метод дає найбільшу імовірність правильного кінцевого результату вивчення явища, що досліджується i надати необхідну інформацію командиру для прийняття рішення. Однак необхідно зауважити що невід'ємною задачею при обробці інформації буде оцінка іiі якості. Тому виникає необхідність розробки методики оцінки якості інформаційноаналітичного забезпечення. Оцінити внесок інформаційно-аналітичного забезпечення в досягнення кінцевої мети підвищення якості роботи автоматизованих інформаційних систем органів управління військового призначення, 3 кількісної точки зору, на сучасному етапі розвитку теорії і практики управління військами є достатньо складною проблемою.

Тому, необхідно мати методику, за допомогою якої можна не тільки оцінити якість інформаційноаналітичного забезпечення, але i обгрунтувати комплекс практичних рекомендацій спрямованих на його удосконалення.

\section{Виклад основного матеріалу дослідження}

Оцінити якість інформаційно-аналітичного забезпечення можна різними способами, але найбільш доцільними $є$ два. Перший полягає в тому, що інформаційно-аналітичне забезпечення оцінюється шляхом співставлення ступеню реалізації можливостей органів управління щодо інформаційно-аналітичного забезпечення організації бойових дій до потенційних можливостей. Другий полягає в тому, що оцінюється відповідність рівня інформаційноаналітичного забезпечення вимогам, що висуваються до нього в конкретній обстановці організації бойових дій (операції). Цей спосіб під час організації бойових дій (операції) має суттєву перевагу над першим способом.

Таке положення визначає i різні потенційні можливості щодо інформаційно-аналітичного забезпечення в залежності від складу i можливостей розвідувальних органів. Тому вже потенційні можливості системи управління можуть не задовольняти необхідному рівню інформаційного забезпечення організації бойових дій (операції).

Другий спосіб дозволяє позбавитись недоліку першого способу i здійснити оцінку якості інформаційно-аналітичного забезпечення з позиції відповідності його вимогам, які висуваються під час організації бойових дій(операції):

адекватності інформаційно-аналітичного забезпечення обстановці, що склалась;

повноти

забезпечення;

корисності

інформаційно-аналітичного забезпечення;

оперативності обробки інформації системою інформаційно-аналітичного забезпечення органу управління .

Тому, пропонується використовувати другий підхід до оцінки якості інформаційно-аналітичного забезпечення органу управління під час організації бойових дій.

В якості критерію в цьому випадку доцільно прийняти вираз виду:

$$
\theta_{\mathrm{i} 3} \geq \theta_{\mathrm{i} 3}^{\Pi}
$$

де: $\theta_{\text {iз }}$ - реалізуємий рівень інформаційноаналітичного забезпечення;

$\theta_{\text {iз }}^{\Pi} \quad-$ потрібний рівень інформаційноаналітичного забезпечення.

В якості часткових показників оцінки інформаційно-аналітичного забезпечення обираємо адекватність інформації та оперативність обробки інформації $[2,4]$.

Адекватність інформаційно-аналітичного забезпечення обстановці що склалась в роботі визначається ступенем адекватності інформаційноаналітичного забезпечення, який характеризує ступінь відповідності інформації стану обстановці яка склалась.

Чисельне значення цього показника розраховується по залежності:

$$
\mathrm{K}_{\mathrm{aд}}=\frac{\sum_{\mathrm{i}=1}^{\mathrm{N}} \sum_{\mathrm{j}=1}^{\mathrm{M}} \mathrm{P}_{\mathrm{ij}}}{\mathrm{D} \cdot \mathrm{R}},
$$

де: $\mathrm{K}_{\text {ад }}$ - ступень адекватності інформаційноаналітичного забезпечення;

D - кількість характеристик тематичного розділу інформації;

$\mathrm{P}_{\mathrm{ij}}$ - показник, який характеризує інформованість органів управління щодо i-й характеристики ј-го розділу інформації;

$\mathrm{R}$ - кількість тематичних розділів інформації;

$\mathrm{N}$ - кількість характеристик інформації;

М - кількість розділів інформації.

Під раціональним рішенням розуміється рішення, яке відповідає обстановці, що склалася i реалізація якого приведе до виконання бойового завдання.

Оперативність обробки інформації системою інформаційно-аналітичного забезпечення органу управління оцінюється часом обробки інформації під час організації бойових дій (операції). Показник чисельно характеризує час, що витрачається органом управління на обробку інформації стану під час проведення процедур перетворення ¥і1 в інформацію управління для виконання бойових завдань.

Використання цього показника обумовлено необхідністю урахування одного 3 найбільш важливих законів управління військами відповідність потрібного часу i часу який $\epsilon$ y розпорядженні.

Як правило, під часом який $є$ у розпорядженні, 
розуміється час директивно встановлений старшим начальником. Але в сучасних умовах, коли 70-80\% об'єктів протиборчої сторони характеризуються як високоманеврені, необхідно враховувати час на протязі якого зміни обстановки не приведуть до значного зниження якості заходів організації бойових дій (операції) - критичний час ( $\mathrm{T}_{\text {кр }}$ ). Тому спираючись на попередні дослідження

$[1,3]$ баланс часу під час організації бойових дій (операції) можна визначити:

$$
\begin{gathered}
\mathrm{T}_{\text {оу }} \leq \mathrm{T}_{\mathrm{p}}, \text { при } \mathrm{T}_{\mathrm{p}} \leq \mathrm{T}_{\text {кр }}, \\
\mathrm{T}_{\text {оу }} \leq \mathrm{T}_{\text {кр }}, \text { при } \mathrm{T}_{\mathrm{p}}>\mathrm{T}_{\text {кр }},
\end{gathered}
$$

де: $\mathrm{T}_{\text {оу }}$ - потрібний час роботи органу управління для організації бойових дій (операції);

$\mathrm{T}_{\mathrm{p}}$ - час, що $\epsilon$ в розпорядженні органу управління на організацію бойових дій (операції);

$\mathrm{T}_{\text {кр }}-$ критичний час роботи органу управління для організації бойових дій (операції).

Інтегральний показник оцінки якості інформаційно-аналітичного забезпечення розраховується за наступним виразом:

$$
\theta_{\mathrm{i} 3}=\mathrm{P}_{\mathrm{i}} \mathrm{K}_{\mathrm{aд}},
$$

де: $\mathrm{P}_{\mathrm{i}}$ - імовірність прийняття рішення, що відповідає обстановці.

Кількісні показники оцінки якості інформаційно-аналітичного забезпечення розраховуються при наступних обмеженнях:

постановка бойового завдання вищим органом управління здійснюється своєчасно;

заходи, що проведені до отримання бойового завдання виконані своєчасно і в повному обсязі;

фізико-географічні фактори для усіх складових органу управління однакові і відповідають умовам оперативного напрямку.

В методиці постійними вихідними даними є:

бойовий склад угруповання протиборчої сторони i можливий характер його дій в збройному конфлікті;

склад військ (сил);

склад системи управління;

перелік заходів що виконуються органом управління під час організації бойових дій (операції);

вплив фізико-географічних умов району бойових дій (операції) на інформаційно-аналітичне забезпечення;

час, що є в розпорядженні органу управління для виконання завдань 3 організації бойових дій (операціі);

можливості протиборчої сторони щодо ведення інформаційної боротьби;

професійна підготовка посадових осіб органу управління на рівні “задовільна".

До змінної інформації відносяться:

обсяг інформації, яку використовує орган управління під час організації бойових дій (операціi) ;

рівень оснащення органу управління засобами електронно-обчислювальної техніки, зв’язку та ACY;

організаційна структура органу управління.

Розроблена методика оцінки якості інформаційно-аналітичного забезпечення дозволяє:

визначити ступінь відповідності інформаційноаналітичного забезпечення вимогам, що висуваються до нього під час організації бойових дій (операції);

розрахувати рівень інформаційно-аналітичного забезпечення організації бойових дій (операціі);

оцінювати внесок розроблених рекомендацій в удосконалення інформаційно-аналітичного забезпечення;

оцінювати економічну доцільність впровадження практичних рекомендацій.

Схема методики оцінки якості інформаційноаналітичного забезпечення організації бойових дій (операції) представлена на рис. 2.

В блоці 1 схеми методики формуються вихідні дані:

можливості протиборчої сторони щодо впливу на інформаційно-аналітичне забезпечення організації бойових дій (операції) ;

фізико-географічні умови району бойового застосування військ (сил);

склад угрупування військ (сил);

бойове завдання угрупування військ (сил $\mathrm{i}$ умови його виконання;

склад, стан і рівень обладнання системи управління органу управління.

В блоці 2 згідно 3 вихідними даними (блок 1) оцінюється обсяг корисної інформації, що $\epsilon$ у органів управління під час організації бойових дій (операції) $\left(P_{i}\right)$.

В блоці 3 згідно 3 визначеною методикою i вихідними даними (блок 1) оцінюється адекватність інформації обстановці, що склалась $\left(K_{a \partial}\right)$.

В блоці 4 згідно з залежністю (1) оцінюється рівень інформаційно-аналітичного забезпечення організації бойових дій (операції) $\left(\theta_{i 3}\right)$.

В блоці 5 на підставі вихідних даних, результатів опитування експертів розраховується потрібний рівень інформаційно-аналітичного забезпечення по залежності:

$$
\theta_{\mathrm{i} 3}^{\Pi}=\mathrm{P}_{\mathrm{i}}^{\Pi} \mathrm{K}_{\mathrm{a} д}^{\Pi},
$$

де: $\theta_{i 3}^{\Pi} \quad-$ потрібний рівень інформаційноаналітичного забезпечення;

$\mathrm{P}_{\mathrm{i}}^{\Pi}$ - потрібна імовірність прийняття рішення, що відповідає обстановці;

$\kappa_{\text {ад }}^{П} \quad-$ потрібний ступень адекватності інформації.

В блоці 6 проводиться аналіз рівня інформаційно-аналітичного забезпечення і відповідність його вимогам, що висуваються під час організації бойових дій (операції). 
Інформаційно-аналітична діяльність у сфері безпеки та оборони

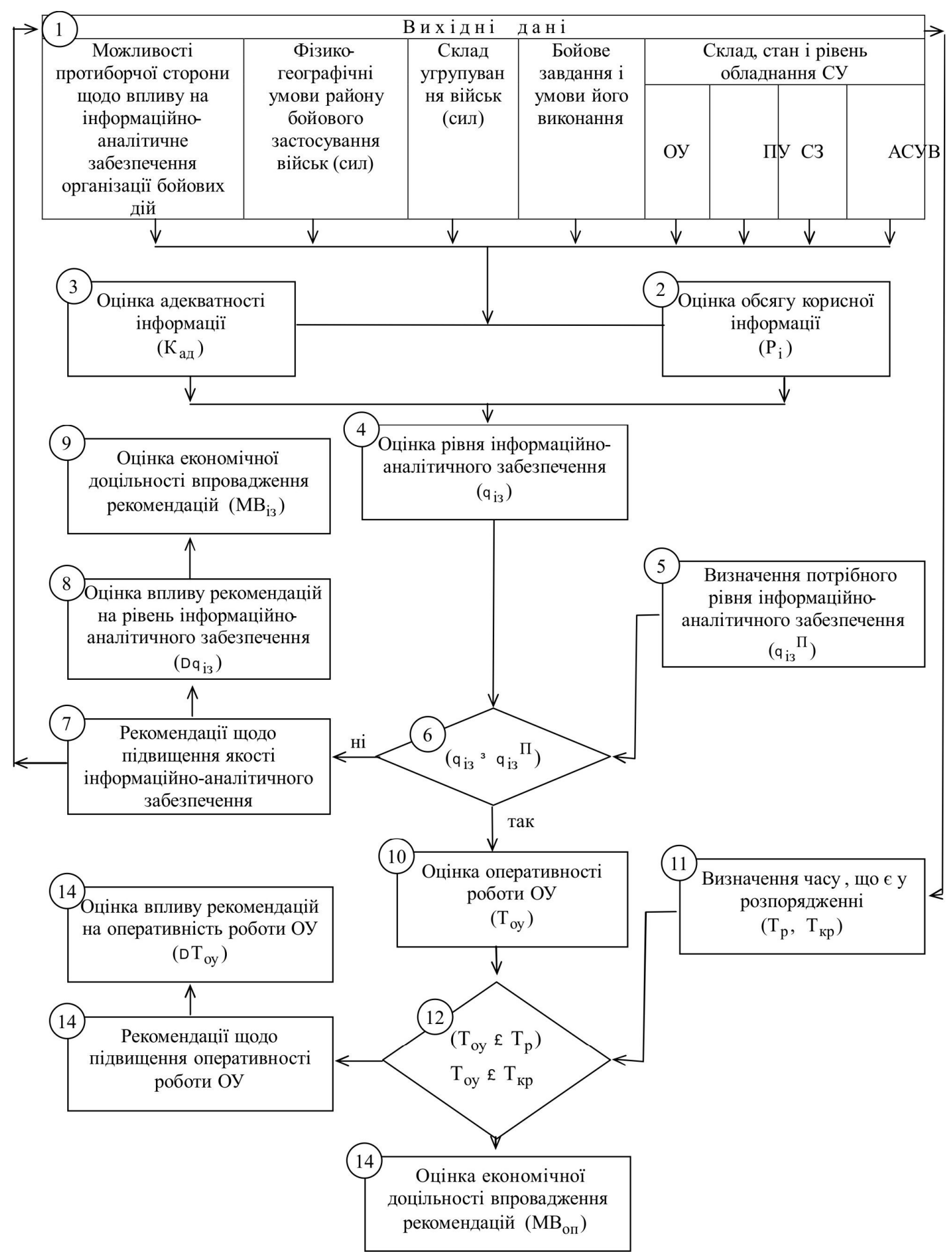

Рис. 2. Схема методики оцінки якості інформаційно-аналітичного забезпечення роботи органу управління

Якщо $\theta_{\text {iз }} \geq \theta_{\text {iз }}^{\Pi} \quad$ інформаційне забезпечення організації бойових дій (операції) відповідає вимогам, що до нього висуваються, якщо ні то його рівень не забезпечує повного виконання завдань організації бойових дій (операції). 3 метою підвищення рівня якості інформаційноаналітичного забезпечення в блоці 7 визначаються причини його невідповідності вимогам, що висуваються.

На підставі визначених причин невідповідності в цьому ж блоці розробляються рекомендації щодо зміни внутрішніх факторів, що впливають на рівень якості інформаційно-аналітичного забезпечення (блок 1) з метою його підвищення. 
В блоці 8 проводиться оцінка впливу розроблених рекомендацій на рівень якості інформаційно-аналітичного забезпечення по залежності:

$$
\Delta \theta_{\mathrm{i} 3}=\frac{\theta_{\mathrm{i} 3}^{*}-\theta_{\mathrm{i} 3}}{\theta_{\mathrm{i} 3}} \cdot 100 \%,
$$

В блоці 9 визначаються матеріальні витрати на одиницю приросту рівня якості інформаційноаналітичного забезпечення по залежності:

$$
\mathrm{MB}_{\mathrm{i} 3}=\frac{\mathrm{S}}{\Delta \theta_{\mathrm{i} 3}},
$$

В цьому ж блоці робляться висновки щодо доцільності практичного впровадження рекомендацій на підставі величини внеску в підвищення рівня якості інформаційноаналітичного забезпечення і матеріальних витрат на їх реалізацію.

В блоці 10 проводиться оцінка оперативності обробки інформації органами управління під час організації бойових дій (операції) $\left(T_{\text {oy }}\right)$.

В блоці 11 визначається час, що $\epsilon$ y розпорядженні органів управління на організацію бойових дій (операції) $\left(T_{p}\right)$ або критичний час. Після отримання абсолютної величини $T_{p}$ i $T_{\kappa p}$ здійснюється їх порівняння. При отриманні балансу: $T_{p}>T_{k p}$ на вхід блоку 12 надходить значення критичного часу. При отриманні балансу $T_{p} \leq T_{\kappa p}$, на вхід блоку 12 надходить значення часу, що $є$ у розпорядженні.

В блоці 12 проводиться аналіз балансу розрахованих показників, що відображають потрібну та реальну оперативність роботи органів управління під час обробки інформації при організації бойових дій (операції). Якщо баланс часу буде дорівнювати $T_{o y} \leq T_{p}$, або $T_{o y} \leq T_{\kappa p}$, органи управління встигнуть своєчасно обробити інформацію під час організації бойових дій (операції). Якщо баланс часу буде іншим, потрібно визначити комплекс заходів (рекомендацій) спрямованих на зменшення потрібного часу роботи органів управління $\left(T_{o y}\right)$ до отримання балансу часу $T_{o y} \leq T_{p}$ або $T_{o y} \leq T_{\kappa p}$. Ці заходи (рекомендації) спрямовані на зміну внутрішніх факторів. Формування рекомендацій, спрямованих на підвищення оперативності обробки інформації органами управління (зменшення часу $T_{o y}$ ) здійснюється в блоці 13 .

В блоці 14 визначається внесок рекомендацій на оперативність роботи органів управління згідно з залежністю:

$$
\Delta \mathrm{T}_{\mathrm{oy}}=\frac{\mathrm{T}_{\mathrm{oy}}-\mathrm{T}_{\mathrm{oy}}^{*}}{\mathrm{~T}_{\mathrm{oy}}} \cdot 100 \%,
$$

В блоці 15 визначаються матеріальні витрати на одиницю зменшення часу на організацію бойових дій (операції) по залежності:

$$
\mathrm{MB}_{\text {оп }}=\frac{\mathrm{S}}{\Delta \mathrm{T}_{\text {oy }}} \cdot 100 \% \text {, }
$$

В цьому ж блоці робиться висновок щодо практичної доцільності впровадження рекомендацій на підставі внеску в зменшення часу роботи органів управління і матеріальних витрат на їх реалізацію.

\section{Висновки й перспективи подальших досліджень}

1. До методів інформаційно-аналітичної підтримки роботи органу управління слід віднести аналогію, метод статистичного аналізу і метод вивчення окремих випадків. Основним методом інформаційно-аналітичної підтримки роботи органу управління доцільно вважати аналогію.

2. Інформаційно-аналітичне забезпечення організації бойових дій (операції) доцільно оцінювати за допомогою показників, які характеризують вимоги, що до нього висуваються.

Кількісно оцінити ступінь відповідності інформаційно-аналітичного забезпечення вимогам, що до нього висуваються можна якщо використовувати в якості головного показника рівень інформаційно-аналітичного забезпечення роботи органу управління під час організації бойових дій (операції) .

Критерієм якості інформаційно-аналітичного забезпечення обрано вираз виду (1).

3. Під час організації бойових дій (операції) до інформацій-аналітичного забезпечення висуваються такі вимоги: адекватність інформаційно-аналітичного забезпечення обстановці, що склалась; оперативність обробки інформації системою інформаційно-аналітичного забезпечення органу управління.

Тому, частковими показниками оцінки якості інформаційно-аналітичного забезпечення обрані: ступінь адекватності інформацйно - аналітичного забезпечення; час, обробки інформації органами управління під час організації бойових дій (операції). Ці показники дозволяють 3 точністю, що допускається, оцінювати не тільки рівень відповідності інформаційно-аналітичного забезпечення вимогам, що до нього висуваються під час організації бойових дій (операції), але i про доцільність розроблених рекомендацій спрямованих на його удосконалення.

4. В основі оцінки якості інформаційноаналітичного забезпечення організації бойових дій (операції) покладена логіко-аналітична методика.

Розроблена методика дозволяє визначити:

ступінь відповідності інформаційноаналітичного забезпечення вимогам, що висуваються до нього під час організації бойових дій (операції);

оцінити якість інформаційно-аналітичного забезпечення організації бойових дій (операції);

оцінювати внесок розроблених рекомендацій в удосконалення інформаційно-аналітичного забезпечення;

оцінювати економічну доцільність впровадження практичних рекомендацій.

5. Методика дає можливість дослідити якість інформаційно-аналітичного забезпечення не тільки під час організації бойових дій (операції), але і в цілому при їх підготовці. 


\title{
Лimepamypa \\ 1. Барабаш Ю.Л. Основи теорії оцінювання Інструкція про порядок підготовки та надання ефективності складних систем.-Київ:вид. НУОУ, 1999.- інформаційно-аналітичних матеріалів про стан ЗСУ для 39c. 2. Положення про Інформаційно-аналітичний центр інформування Адміністрації Прзидента України, Головного командного центру Збройних Сил України.- $\quad$ Кабінету Міністрів України, Ради національної безпеки і К.: МОУ,2012.-51с. 3. Левкин И.М. Основы оборони України, Миіністра оборони України.-к.: МОУ, информационно-аналитической работы.-СПб.:СЗАГС, 2014.-155c. 2004.С.14-35. 4. Наказ МОУ від 29.01.14 №74. \\ МЕТОДИКА ОЦЕНКИ КАЧЕСТВА ИНФОРМАЦИОННО-АНАЛИТИЧЕСКОГО ОБЕСПЕЧЕНИЯ РАБОТЫ АВТОМАТИЗИРОВАННЫХ ИНФОРМАЦИОННЫХ СИСТЕМ ОРГАНОВ УПРАВЛЕНИЯ ВОЕННОГО НАЗНАЧЕНИЯ
}

\author{
Александр Валериевич Крайнов (кандидат технических наук, доцент) ${ }^{1}$ \\ Роман Иванович Грозовский ${ }^{1}$ \\ Анатолий Анатольевич Кравчук ${ }^{2}$
}

\begin{abstract}
${ }^{1}$ Национальный университет обороны Украины имени Ивана Черняховского, Киев, Украина ${ }^{2}$ Военный институт Киевского национального университета имени Тараса Шевченко, Киев, Украина
\end{abstract}

Одной из приоритетных задач оборонной реформы является создание эффективной системы управления военного назначения. Важную роль в реализации этой задачи играть внедрения 6 деятельность органов управления и войск (сил) современных информационных технологий, адаптация лучших практик и стандартов ведущцих стран НАТО, комплексная автоматизация процессов оперативного (боевого) управления, связи, разведки и наблюдения (C4ISR), учета и управления оборонными ресурсами (DRMIS). Проблемным вопросом остается осуществления и выполнения заказов по созданию автоматизированных информационных систем органов управления военного назначения, информационно-аналитического обеспечения их работы и информационной инфраструктуры, поскольку в Украине в настоящее время отсутствуют государственные организации и частные предприятия, которые способны самостоятельно выполнять весь комплекс работ и услуг по создание автоматизированных информационных систем и развертывания информационной инфраструктуры.

Ключевые слова: автоматизированная информационная система; информационноаналитическое обеспечение; органа военного управления; качество.

\section{QUALITY ASSESSMENT METHOD OF INFORMATION-ANALYTICAL SUPPORT OF WORK OF AUTOMATED INFORMATION SYSTEMS OF MILITARY MANAGEMENT BODIES}

\author{
Oleksandr Krainov (Candidate of technical sciences, associate professor) ${ }^{1}$ \\ Roman Hrozovskyi ${ }^{1}$ \\ Anatolii Kravchuk ${ }^{2}$ \\ ${ }^{1}$ National Defence University of Ukraine named after Ivan Cherniakhovsky, Kyiv, Ukraine \\ ${ }^{2}$ Military Institute, Taras Shevchenko National University of Kyiv, Kyiv, Ukraine
}

One of the priorities of defense reform is to create an effective military management system. An important role in the implementation of this task will be played by the introduction of modern information technologies into the management and forces (forces), adaptation of the best practices and standards of leading NATO member states, integrated automation of operational (combat) command, communication, intelligence and surveillance (C4ISR) processes. ), Defense Accounting and Management (DRMIS). The problem remains the implementation and implementation of orders for the creation of automated information systems for military administration, information and analytical support of their work and information infrastructure, since in Ukraine at present there are no state organizations and private enterprises that are able to independently perform the whole range of works and services with creation of automated information systems and deployment of information infrastructure.

Keywords: automated information system; information and analytical support; a military management body; quality.

\section{References}

1. Barabash Yu.L. Fundamentals of the Theory of Estimating the Efficiency of Complex Systems. -Kyiv: View. NUOU, 1999.-39s. 2. Regulations on the Information and Analytical Center of the Main Command Center of the Armed Forces of Ukraine. -K .: MOU, 2012.-51s. 3. Levkin I.M. Fundamentals of information and analytical work. Spb: SZAGS, 2004.S.14-35. 4. Order of the MOE of
January 29, 1474, No. 74. Instruction on the procedure for preparing and providing information and analytical materials on the state of the Armed Forces of Ukraine to inform the Administration of the President of Ukraine, the Cabinet of Ministers of Ukraine, the National Security and Defense Council of Ukraine, and the Ministry of Defense of Ukraine. -M .: MOE, 2014-2015. 